\title{
SYNTHESIS AND SPECTRAL CHARACTERIZATION OF Fe(II) AND Mn(II) COMPLEXES WITH ORAL FLUOROURACIL PRO-DRUG CAPECITABINE
}

\author{
A. Cipurković ${ }^{1, *}$, E. Horozić ${ }^{1}$, N. Ljubijankić ${ }^{2}$, A. Odobašić ${ }^{3}$, \\ S. Galijašević ${ }^{4}$ and M. Saletović ${ }^{1}$ \\ ${ }^{1}$ Department of Chemistry Faculty of Natural Science and Mathematics, University of Tuzla, \\ Univerzitetska 4, Tuzla 75 000, Bosnia and Herzegovina \\ 2 Department of Chemistry Faculty of Natural Science and Mathematics, University of Sarajevo, \\ Zmaja od Bosne 33-35, Sarajevo 71000, Bosnia and Herzegovina \\ ${ }^{3}$ Department of Physical Chemistry and Electrochemistry Faculty of Technology, \\ University of Tuzla, Univerzitetska 8, Tuzla 75 000, Bosnia and Herzegovina \\ ${ }^{4}$ Medical School, Sarajevo School of Science and Technology, Hrasnička cesta 3a, Ilidža, \\ Sarajevo 71 000, Bosnia and Herzegovina \\ *E-mail: amira.cipurkovic@untz.ba
}

\begin{abstract}
Malignant neoplasms are today one of the leading causes of death in the world. Their treatment is extremely complex and requires the application of various chemical compounds which leads to disruption of homeostasis in the human body. During a treatment, there is a possibility of complex formation with important bioelements, such as copper, iron, cobalt, manganese, and others in the biological system. This paper presents the results of possible formation of complexes between $\mathrm{Fe}(\mathrm{II})$ and $\mathrm{Mn}(\mathrm{II})$ ions and capecitabine (IUPAC name: pentyl 1-( $(2 R, 3 R, 4 S, 5 R)-3,4-$ dihydroxy5-methyl-tetra- hydrofuran-2-yl)-5-fluoro-2-oxo-1,2-dihydropyrimidin-4-yl carbamate). This chemotherapeutic agent is often used for the treatment of different solid tumors including breast, colon, prostate, liver and gastrointestinal tract carcinoma. Spectroscopic methods (UV/Vis and FT-IR spectroscopy) were used in order to research specific compounds between CPC and metal ions that may be formed in human body under physiological and approximately physiological conditions. In addition, microscopic characterization and comparison of solid samples of capecitabine and products of interactions of CPC as a ligand with Fe(II) and Mn(II) ions have been performed. FT-IR spectra indicate the existence of interaction of these two divalent bio cations with CPC, i.e. their coordination through nitrogen and oxygen atoms of CPC. When UV spectra of pure ligand and model systems M(II)-CPC were compared, similar absorption bands were observed with absorption maxima at the same wavenumbers but lower absorbance values for model systems M(II)-CPC.
\end{abstract}

Keywords: CPC, bio-metal cations, complex, FT-IR, UV, microscopic analyze

@) RASĀYAN. All rights reserved

\section{INTRODUCTION}

In biological systems, bio-metal ions can interact with molecules that are present as constituents of living cells, or are entered into the body with foods or pharmaceuticals. These interactions are important in terms of the utilization of bio-metals in the organism, their distribution, and retention in the organism, as well as for potential elimination from the organism. Formation of the association may also result in specific chemical species as integral parts of tissue or body fluids, which can lead to increased solubility of the metal in the body. There are literature data about investigations of interaction between bio-metal ions and numerous ligands and synthesis of formed products.

The study of the interaction of bio-metal ion M(II) and O-donor ligand (used as a drug) is interesting for several important reasons: in order to achieve a uniform drug dosage and bio-distribution, monitoring its

Rasayan J. Chem., 10(4), 1381-1390(2017)

http://dx.doi.org/10.7324/RJC.2017.1041905 
pharmacokinetic and excretion, better antimicrobial, antitumor and antiulcer activity, and reduction of undesirable effects of the drug. ${ }^{1,2,3}$ According to the literature data, products of the interaction of M(II) ions with $\mathrm{N}$-donor ligands were studied by the spectroscopic methods in order to obtain a pharmaceutical product with better pharmacological and antitumor effects. ${ }^{4,5}$

In this paper, the interactions of $\mathrm{Fe}$ (II) and $\mathrm{Mn}$ (II) ions with an antitumor drug named capecitabine (CPC) were studied by FT-IR and UV/Vis spectroscopy and obtained products were closely defined. Model test systems were prepared for the interaction of $\mathrm{M}$ (II) ions with CPC in approximately physiological conditions. Samples of solid products were also microscopic studied.

Pentyl-1-((2R,3R,4S,5R)-3,4-dihydroxy-5-methyl-tetrahydrofuran-2-yl)-5-fluoro-2-oxo-1,2-

dihydropyrimidin-4-yl carbamate (hereinafter capecitabine) is a cytotoxic anticancer agent used for monotherapy of patients with colon cancer (Dukes' stage $C$ by classification) or combined therapy in advanced colorectal, gastric and locally advanced breast cancer. ${ }^{6,7}$ The activation of capecitabine is a threestep enzymatic process. ${ }^{8}$ The structure of this compound is shown in Fig.-1.

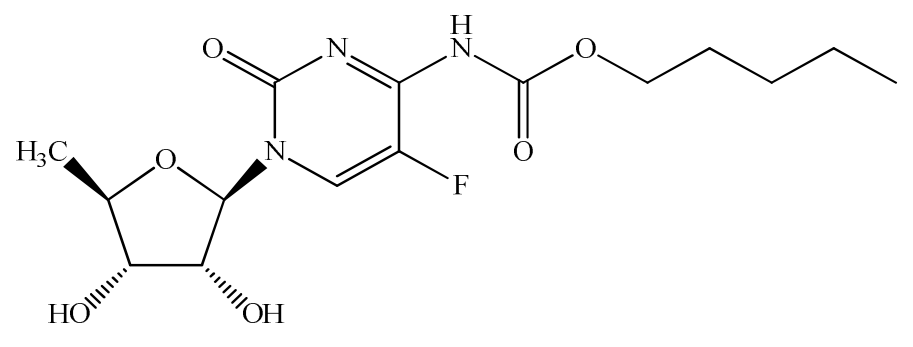

Fig.-1: Structural formula of Capecitabine ${ }^{9}$

Capecitabine belongs to a group of drugs called antimetabolites. ${ }^{10}$ It is administered orally to the organism, by tablets. ${ }^{11}$ Capecitabine is enzymatically activated in three steps forming two intermediary metabolites, 5'-deoxy-5-fluorocytidine (5'-DFCR) and 5'-deoxy-5-fluorouridine (5'-DFUR), which forms 5-fluorouracil. The metabolism of formation of 5'-deoxy-5-fluorocytidine occurs by the carboxylesterase (CE) activity in the liver. The resulting product is then converted to the 5 -deoxy-5-fluorouridine (5 -DFUR) by the activity of cyd deaminase (Cyd). In cancer cells resulting 5-DFUR is converted to 5-fluorouracil (5-FU). ${ }^{12} 5$-FU takes the role of a pyrimidine, blocks the growth of tumor cells and ultimately cause their destruction..$^{13,14}$ Figure 2. shows major end products of metabolic pathway of CPC. ${ }^{15}$

As the oncologists cite, intracellular anabolism of 5-fluorouracil (5-FU) is very complex. The formed complex named 5-fluorouridine-5'-triphosphate (5-FUTP) can be incorporated into RNA instead of uridine5'-triphosphate (UTP), while the complex named 5-fluoro-2'-deoxyuridine-5'-triphosphate (5-FdUTP) can be incorporated into DNA because it acts as a substrate for DNA polymerases. Oncologists suppose that more than $80 \%$ of the injected dose of 5-FU is degraded after administration. The proposed mechanism of catabolic degradation of 5-FU consists of three stages. In the last stage, several catabolites of 5-FU are identified, but $\alpha$-fluoro- $\beta$-alanine (FBAL) is formed as the major catabolite of 5-FU. ${ }^{16}$

Iron and manganese are essential elements in the body, and are required for many biochemical reactions. Iron belongs to d-block transition elements and can exist in oxidation states ranging from -2 to +6 . In biological systems, iron primarily exists in next oxidation states: +2 (ferrous), +3 (ferric) and +4 (ferryl) ${ }^{17}$ All living organisms contain iron-proteins: Archaeans, bacteria and eukaryotes, including humans. In the human body, iron mainly exists in complex forms bound to heme compounds (hemoproteins and hem enzymes), or nonhuman compounds (flavin-iron enzymes, transferrin, and ferritin). ${ }^{18}$ Classification of major iron-containing proteins is shown in Fig.-3.

In almost all cells, iron is indispensable as a cofactor for fundamental biochemical activities (as oxygen transport, energy metabolism, and DNA synthesis). ${ }^{19}$ Iron concentration in tissues is well-regulated. Increased amounts lead to the tissue damage as a result of free radical formation via Fenton reaction. ${ }^{20,21}$ Many proteins contain binuclear manganese centers (catalases, thiosulfate oxidase, dinitrogen reductase regulatory protein, and aminopeptidases and $\lambda$ protein phosphatase).${ }^{22}$ Divalent manganese is also an active 
RASĀYAN J. Chem.

Vol. 10 | No. 4 |1381-1390 | October - December | 2017

center of the enzyme arginase. The arginases takes part in the cycle of urea as the final product of nitrogen metabolism. These enzymes catalyze the hydrolysis of L-arginine to form the nonprotein amino acid Lornithine and urea. This reaction constitutes the final step in urea biogenesis in the liver. ${ }^{23}$

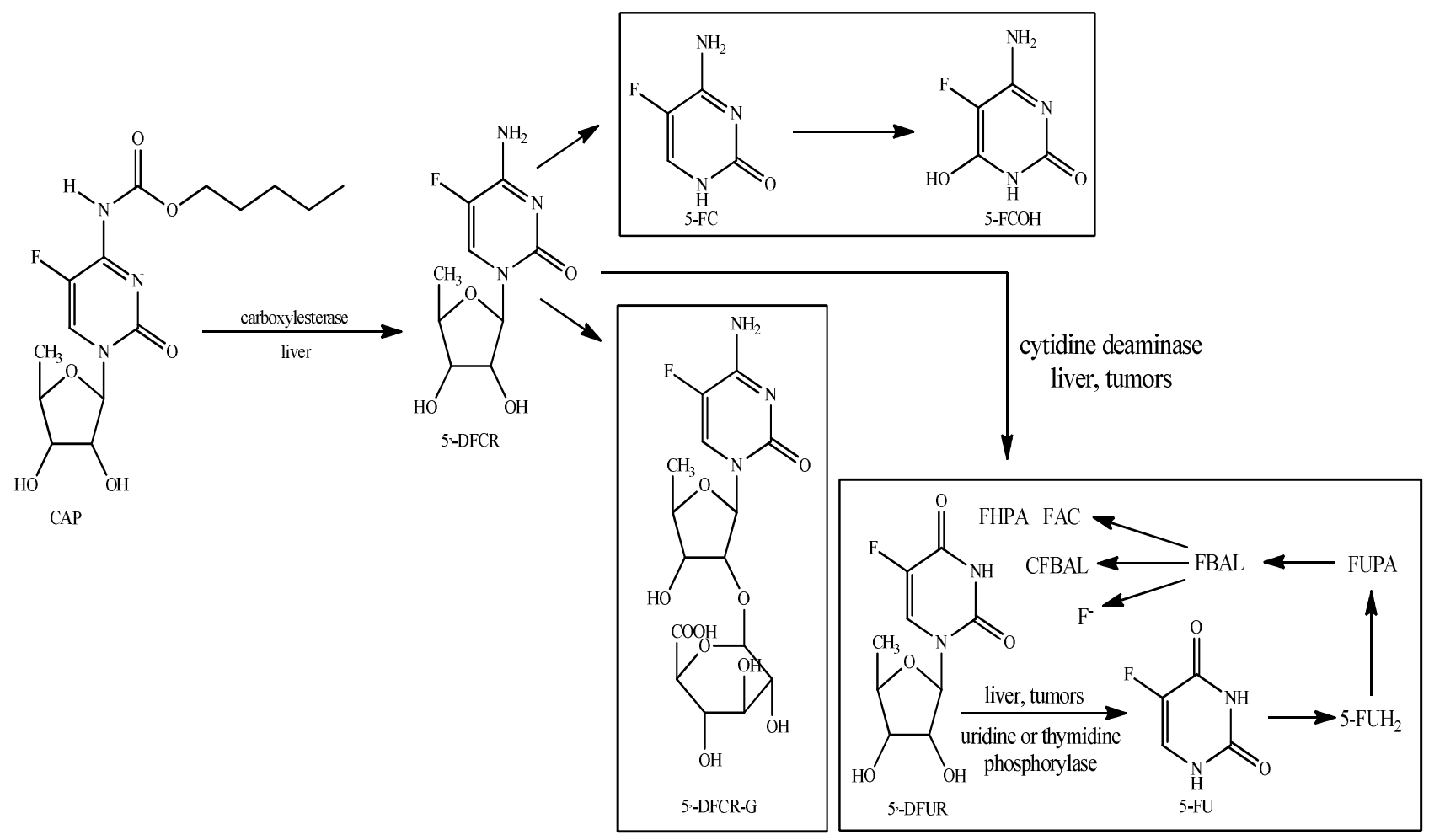

Fig.-2: Metabolic end products of capecitabine pathway ${ }^{15}$

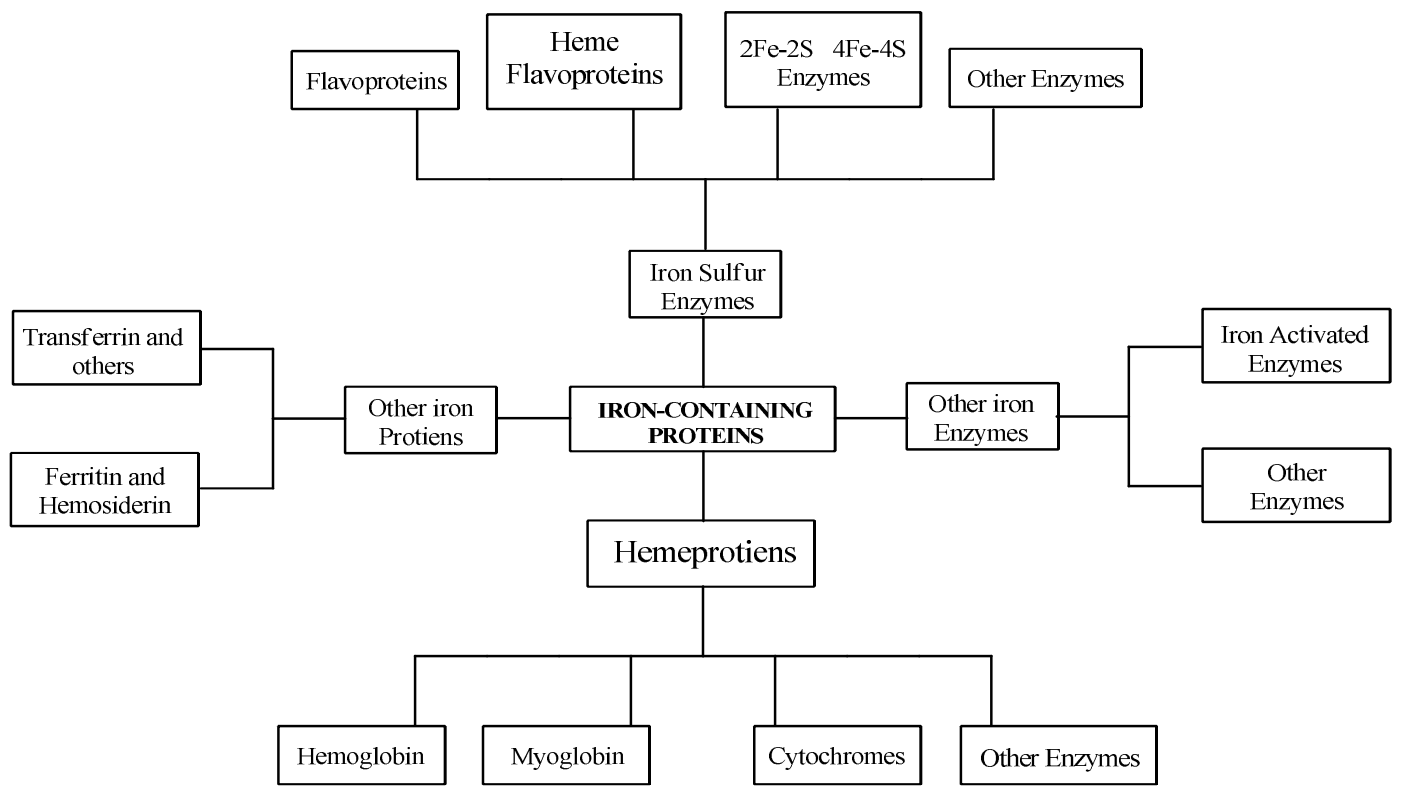

Fig.-3: Classification of major iron-containing proteins ${ }^{17}$ 
RASĀYAN J. Chem.

Vol. 10 | No. 4 |1381-1390 | October - December | 2017

Arginase is one of the best-studied non-redox enzymes, which structure is shown in Figure 4. Two Mncenters are bridged through hydroxide which hydrogen forms H-bond with uncoordinated oxygen atom of Asp-128 residue. $^{24}$

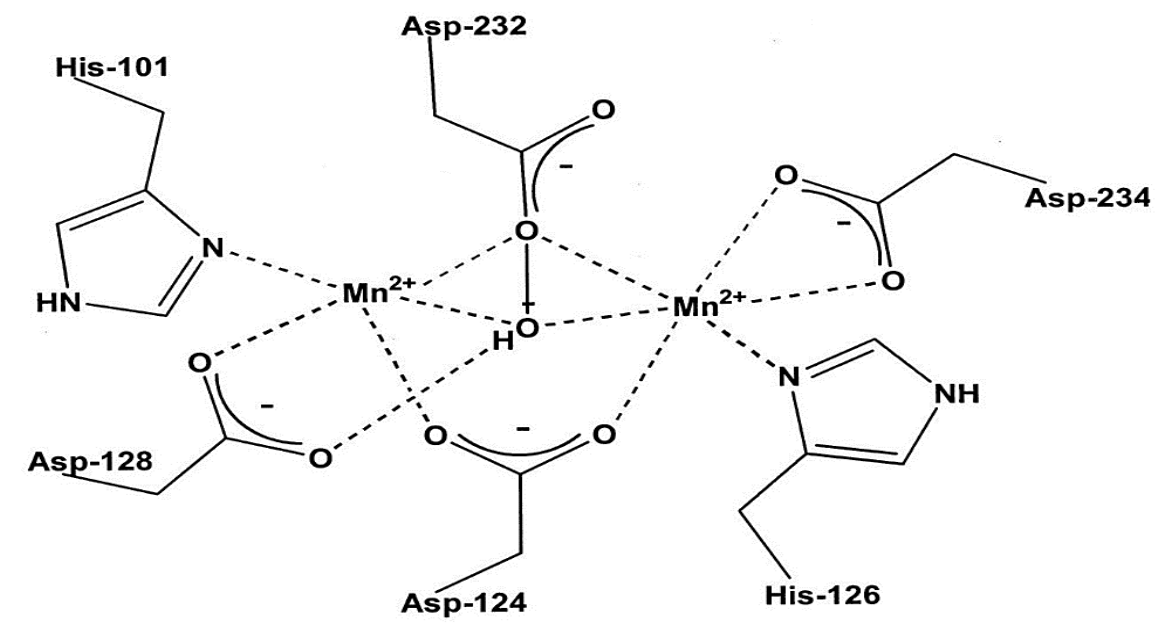

Fig.-4: Binuclear center of rat liver arginase $\mathrm{I}^{25}$

\section{Materials and Methods}

\section{EXPERIMENTAL}

Spectroscopic methods (UV and FT-IR) were used in order to investigate the potential occurrence of associates between CPC-ligand and metal salt solutions. Also, microscopic characterization of pure ligand and solid products of M(II)-CPC interactions were performed in order to determine differences in color, size, and shape of crystals. Two bio-metals, $\mathrm{Fe}(\mathrm{II})$ and $\mathrm{Mn}$ (II) were used for investigations of interaction with CPC. Iron ions were used in the form of $\mathrm{FeSO}_{4} \cdot 7 \mathrm{H}_{2} \mathrm{O}$, and manganese ions were used in the form of chloride $\left(\mathrm{MnCl}_{2} \cdot 4 \mathrm{H}_{2} \mathrm{O}\right)$.

\section{Synthesis of M(II)-CPC complex for FT-IR analyze}

A mixture of ethanol and water in a volume ratio 1:1 was used as a solvent for metal salts and CPC. These solutions were mixed in molar ratios of $\mathrm{M}(\mathrm{II}): \mathrm{L}=1: 2(\mathrm{n} / \mathrm{n})$. Concentrations of the stock solutions and $\mathrm{pH}$ values of reaction systems are shown in Table 1.

Table-1: Compositions of M(II)-CPC systems prepared for obtaining solid products to be analyzed by FT-IR spectroscopy

\begin{tabular}{ccccc}
\hline Solution of salts & $\mathrm{pH}$ & $\mathrm{c}-\mathrm{Ksp}\left[\mathrm{mol} \mathrm{dm}^{-3}\right]$ & $\mathrm{c}(\mathrm{M})\left[\mathrm{mol} \mathrm{dm}^{-3}\right]$ & $\mathrm{c}(\mathrm{CPC})\left[\mathrm{mol} \mathrm{dm}^{-3}\right]$ \\
\hline $\mathrm{FeSO}_{4} \cdot 7 \mathrm{H}_{2} \mathrm{O}$ & 7.30 & $<0.129$ & 0.02 & 0.04 \\
$\mathrm{MnCl}_{2} \cdot 4 \mathrm{H}_{2} \mathrm{O}$ & 7.30 & $<5.26$ & 0.02 & 0.04 \\
\hline
\end{tabular}

Metal salt $\left(15 \mathrm{~cm}^{3}\right)$ and CPC $\left(15 \mathrm{~cm}^{3}\right)$ solutions were mixed in a beaker and stirred with a magnetic mixer without heating, adjusting $\mathrm{pH}$ values of systems on $\mathrm{pH}$-meter. After stirring reaction mixtures, separation of solid products was observed in both of them. Reaction mixtures were kept in dark area, at the room temperature for three days. Solid precipitates formed were red-brown in solution with $\mathrm{FeSO}_{4}$, and beige in solution with $\mathrm{MnCl}_{2}$.

The supernatant in both cases was colorless and transparent. The solid products were separated by filtration on filter paper (blue ribbon), and thereafter dried in an oven at a temperature range of $40-50^{\circ} \mathrm{C}$. Colors of substances did not change, indicating that they are stable at room temperature. 


\section{FT-IR spectroscopic characterization}

Infrared spectroscopy with Fourier transformation was used to determine CPC and metal ions interaction, model. IR spectra were recorded by technique $\mathrm{KBr}$ pastilles, (pressing a mixture of the test sample and $\mathrm{KBr}$ ). About $1.5 \mathrm{mg}$ of sample and $150 \mathrm{mg}$ of $\mathrm{KBr}$ were measured and applied to form $\mathrm{KBr}$ pellet. The obtained mixture was homogenized and further compressed in the special mold by a hydraulic press. A thin, round pastille was obtained in this way.

Spectra were recorded on Perkin Elmer Spectrum BX FT-IR device, in the wavelength region from 4000 to $450 \mathrm{~cm}^{-1}$, resolution $2 \mathrm{~cm}^{-1}$ at room temperature $\left(25^{\circ} \mathrm{C}\right)$ in the laboratory of Pharmacy, University of Tuzla. Possibly coordination of CPC with Fe(II) and Mn(II), i.e. the primary structure of the coordination sphere of the resulting product, were analyzed by recording IR spectra of pure CPC and products of its reaction with $\mathrm{Fe}(\mathrm{II})$ and $\mathrm{Mn}(\mathrm{II})$ ions.

\section{UV spectroscopic characterization}

The solutions of metal salts and ligands were prepared by dissolving them in an ethanol-water solution in volume ratio 50/50. Concentrations of working solutions were of the order of $10^{-6} \mathrm{~mol} \mathrm{dm}^{-3}$. The concentration of CPC was $0.32 \cdot 10^{-6} \mathrm{~mol} \mathrm{dm}{ }^{-3}$, concentrations of metal ions were $0.16 \cdot 10^{-6} \mathrm{~mol} \mathrm{dm}^{-3}$. After stirring in a volume ratio of $1: 1$, samples were left in dark place for two hours, after which their absorption spectra were recorded.

Absorption spectra of pure ligand (CPC) and products of interaction M(II)-CPC occurred after mixing of solutions, were recorded on double-bean UV/VIS spectrophotometer, Perkin Elmer $\lambda 25$, in the range of wave numbers from 200 to $400 \mathrm{~nm}$ (Research Laboratory at the Department of Physical Chemistry and Electrochemistry, Faculty of Technology, University of Tuzla). Recordings of samples were performed at room temperature $\left(25^{\circ} \mathrm{C}\right)$ in quartz cuvettes; optical path length $1=1.0 \mathrm{~cm}$; deuterium lamp as a light source.

\section{Microscopic analyze}

Pure CPC and separated solid products after interactions were subjected to a microscopic analysis comparing color, texture and particle size. Recordings were carried out at the binocular microscope Leica DM 2500P. The samples are recorded in polarized light with and without cross Nicol's (XPL and PPL).

\section{The structure of the M(II) CPC complex}

\section{RESULTS AND DISCUSSION}

Solutions of CPC and metal salts were mixed in the molar ratio 2:1, and the reaction scheme is shown in Fig.-5.

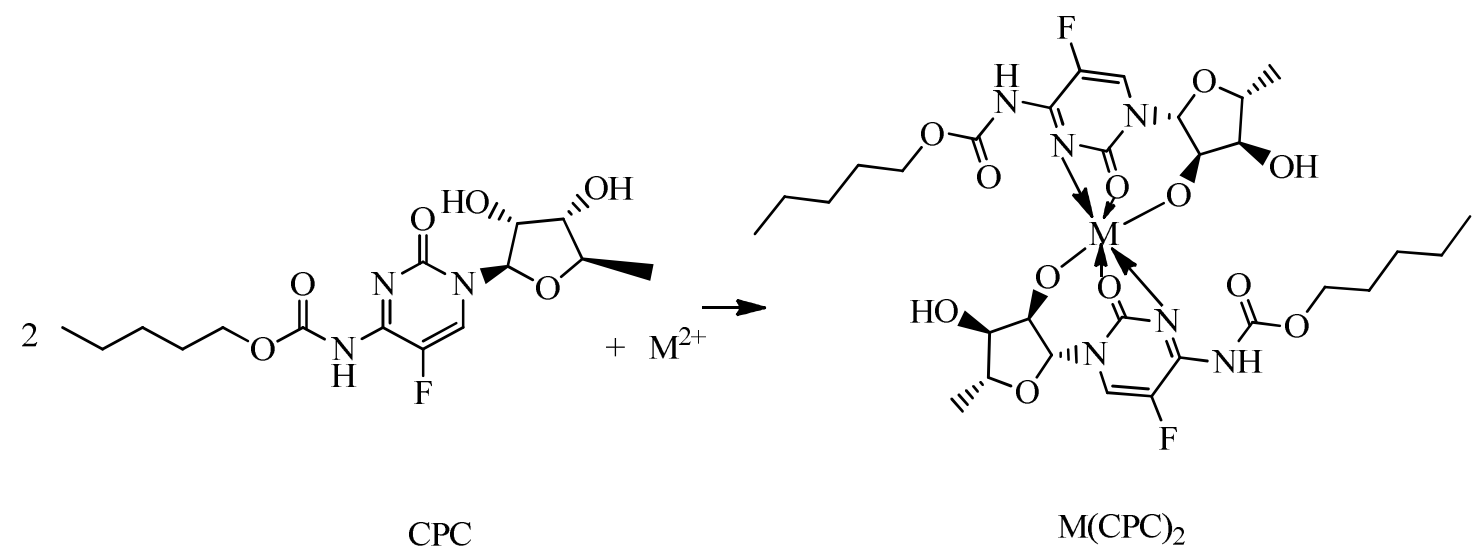

Fig.-5: Reaction scheme between CPC and M(II) salts

Due to the presence of $\mathrm{N}$ and $\mathrm{O}$ donor atoms, CPC acts as a ligand and in the reaction with $\mathrm{Mn}$ (II) salts leads to its coordination to the metal center. It is assumed that CPC coordinates as tridentate ONO donor ligand, occupying all six coordination positions of $\mathrm{Fe}(\mathrm{II})$ or $\mathrm{Mn}(\mathrm{II})$ ions in a molar ratio of CPC:M(II) = $2: 1$.

Fe(II) AND Mn(II) COMPLEXES 
The reaction products, solids red-brown and beige colors, $\mathrm{CPC}-\mathrm{Fe}(\mathrm{II})$ and $\mathrm{CPC}-\mathrm{Mn}(\mathrm{II})$, respectively, are neutral, tridentate complex compounds of the type $\mathrm{M}(\mathrm{CPC})_{2}$.

\section{FT-IR spectra}

Figure-6 shows FT-IR spectrum of pure CPC.

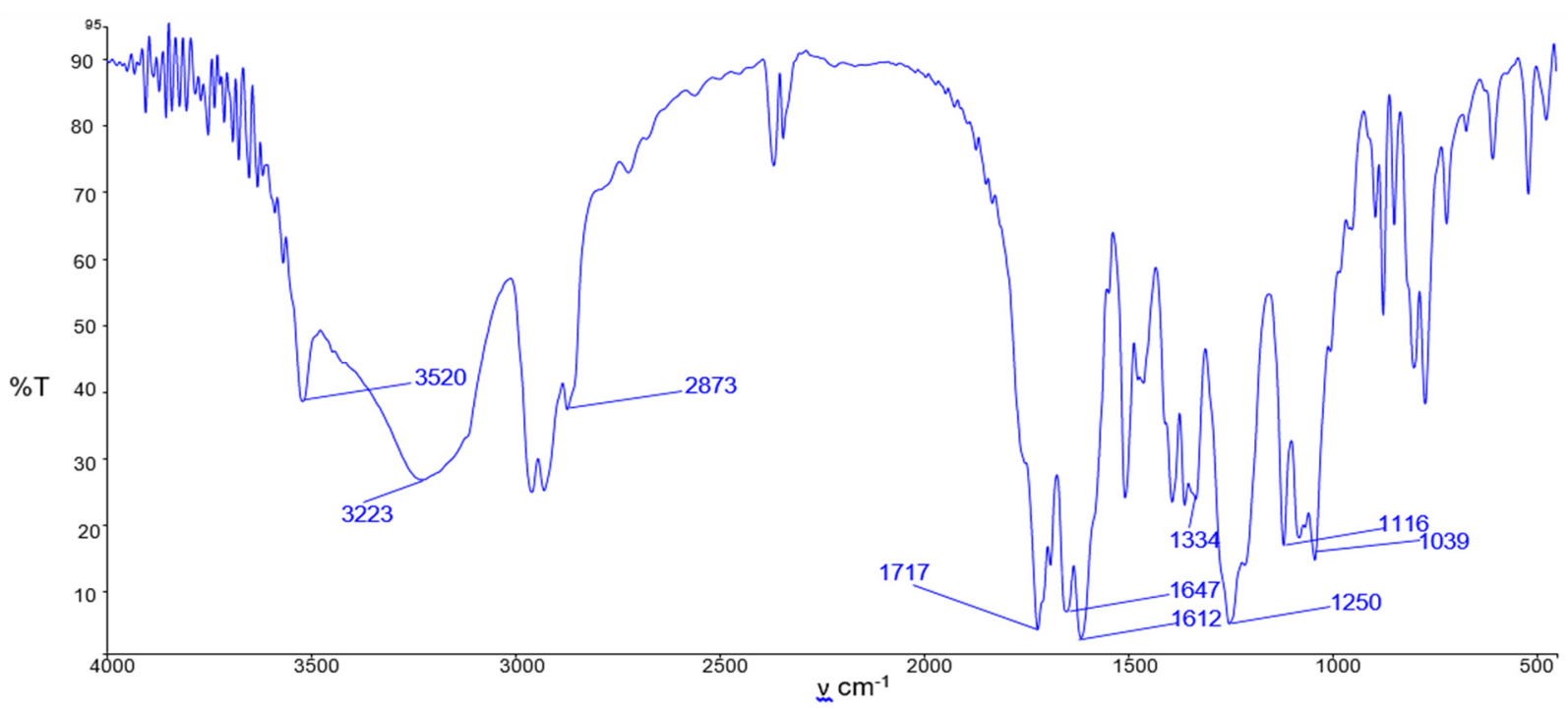

Fig.-6: FT-IR spectrum of pure CPC

Pure CPC showed characteristic IR absorption bands at $1039 \mathrm{~cm}^{-1}$ indicating the presence of C-N group, $1116 \mathrm{~cm}^{-1}$ were thought to be C-O-C group, $1250 \mathrm{~cm}^{-1}$ indicates the presence of C-O bond, $1334 \mathrm{~cm}^{-1}$ indicates the presence of $\mathrm{C}-\mathrm{F}$ bond, $1612 \mathrm{~cm}^{-1}$ indicates the presence of $\mathrm{C}=\mathrm{N}$ group, $1647 \mathrm{~cm}^{-1}$ indicates the presence of carbonyl $\mathrm{C}=\mathrm{O}$ group in aromatic ring, $1717 \mathrm{~cm}^{-1}$ indicates the presence of stretching of carbonyl $\mathrm{C}=\mathrm{O}$ group of carbamate urethane group, 2873 were thought to be $\mathrm{C}-\mathrm{H}$ stretching (alkane), 3223 $\mathrm{cm}^{-1}$ indicates the presence of stretching of OH group (H-bond) and $3520 \mathrm{~cm}^{-1}$ stretching of the unassociated $\mathrm{OH}$ group. ${ }^{26,}{ }^{27}$ FT-IR spectra of $\mathrm{Fe}(\mathrm{CPC})_{2}$ and $\mathrm{Mn}(\mathrm{CPC})_{2}$ complexes are shown in Fig.-7 and 8, respectively.

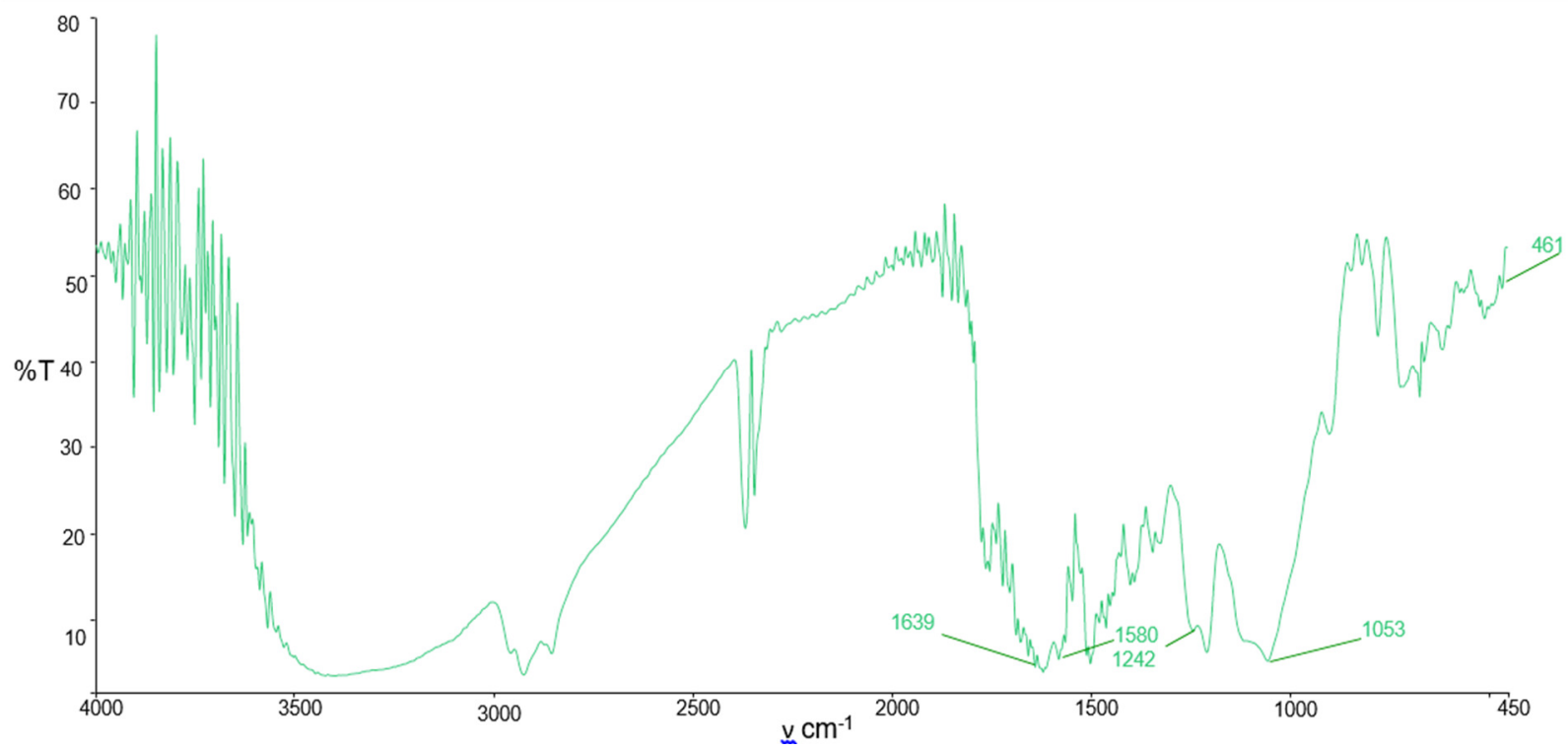

Fig.-7: FT-IR spectrum of complex $\mathrm{Fe}(\mathrm{CPC})_{2}$ 
RASĀYAN J. Chem.

Vol. 10 | No. 4 |1381-1390 | October - December | 2017

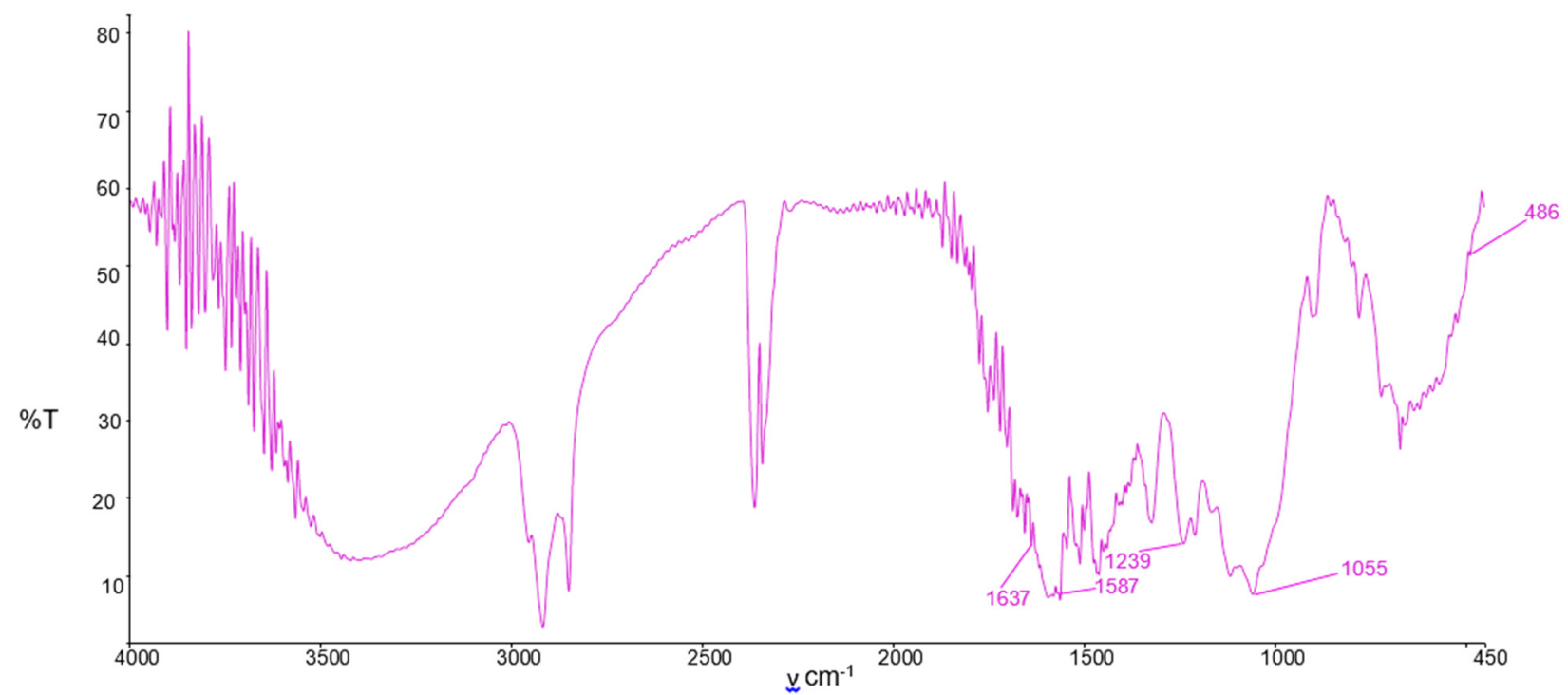

Fig.-8: FT-IR spectrum of complex $\mathrm{Mn}(\mathrm{CPC})_{2}$

The comparison FT-IR spectra of pure CPC with $\mathrm{Fe}(\mathrm{CPC})_{2}$ and $\mathrm{Mn}(\mathrm{CPC})_{2}$ complexes are shown in Fig.-9.

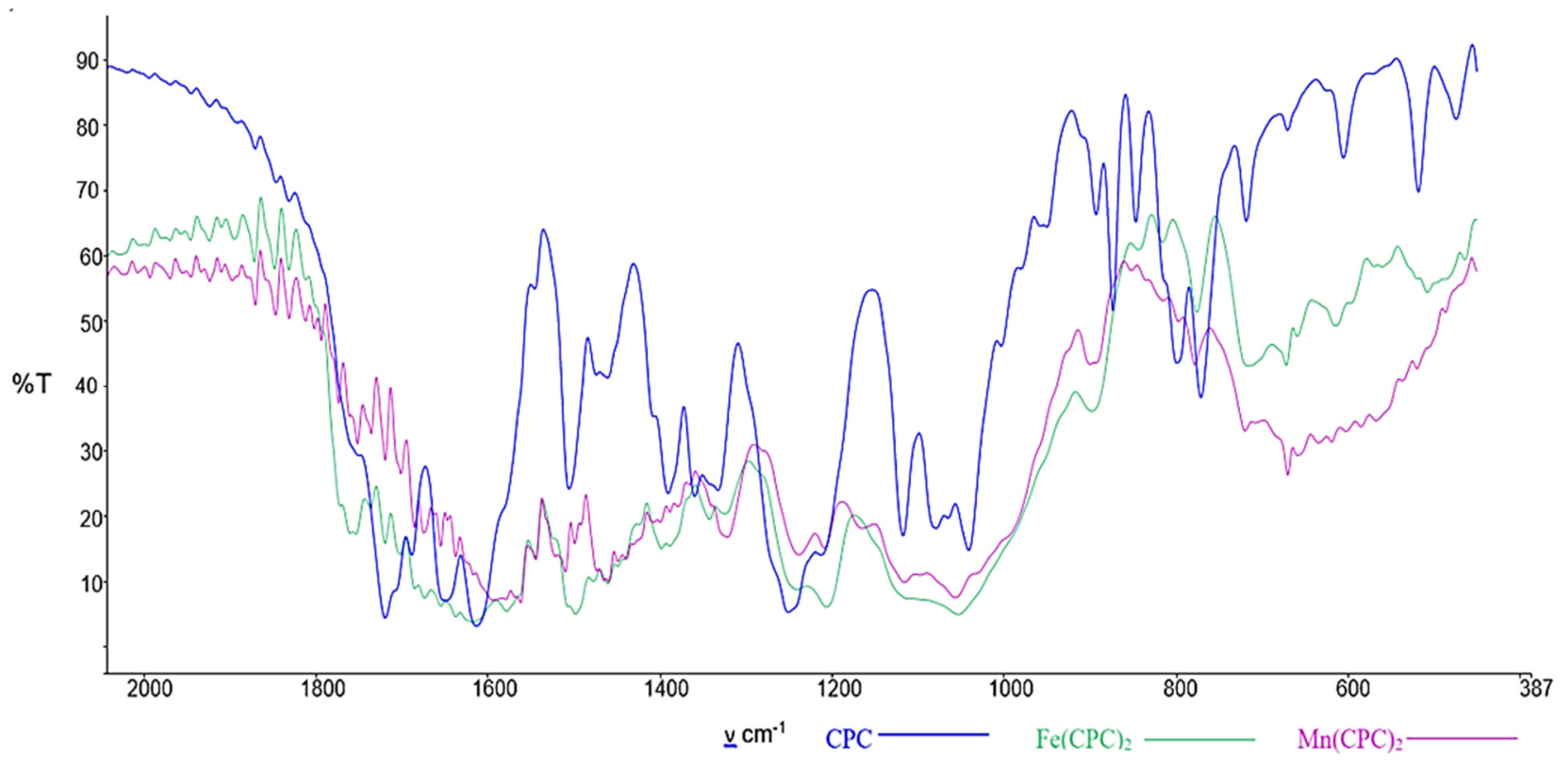

Fig.-9: Comparative FT-IR spectra of CPC and complexes $\mathrm{Fe}(\mathrm{CPC})_{2}$ and $\mathrm{Mn}(\mathrm{CPC})_{2}$

Table-2 shows the characteristic vibrations of pure $\mathrm{CPC}$ and complexes $\mathrm{Fe}(\mathrm{CPC})_{2}$ and $\mathrm{Mn}(\mathrm{CPC})_{2}$.

Table-2: Characteristic vibrations of $\mathrm{CPC}, \mathrm{Fe}(\mathrm{CPC})_{2}$ and $\mathrm{Mn}(\mathrm{CPC})_{2}$

\begin{tabular}{cccccc}
\hline $\mathrm{CPC} / \mathrm{CPC}-\mathrm{M}$ & $v(\mathrm{C}=\mathrm{N}), \mathrm{cm}^{-1}$ & $v(\mathrm{C}=\mathrm{O}), \mathrm{cm}^{-1}$ & $v(\mathrm{C}-\mathrm{O}), \mathrm{cm}^{-1}$ & $v(\mathrm{C}-\mathrm{N}), \mathrm{cm}^{-1}$ & $v(\mathrm{M}-\mathrm{O}), \mathrm{cm}^{-1}$ \\
\hline $\mathrm{CPC}$ & 1612 & 1647 & 1250 & 1039 & - \\
$\mathrm{Fe}(\mathrm{CPC})_{2}$ & 1580 & 1639 & 1242 & 1053 & 461 \\
$\mathrm{Mn}(\mathrm{CPC})_{2}$ & 1587 & 1637 & 1239 & 1055 & 486 \\
\hline
\end{tabular}


RASĀYAN J. Chem.

Vol. 10 | No. 4 |1381-1390 | October - December | 2017

Changes in IR spectra of pure CPC and the resulting compounds are evident by shifts of symmetric stretching $\mathrm{C}=\mathrm{O}$ and $\mathrm{C}=\mathrm{N}$ bond, symmetric stretching $\mathrm{C}-\mathrm{O}(\mathrm{H} / \mathrm{M})$ bonds before and after coordination, and identification of new bands in low-wave range.

Symmetric stretching of $\mathrm{C}=\mathrm{N}$ groups in spectra of pure $\mathrm{CPC}$ is attributed to the absorption band at 1612 $\mathrm{cm}^{-1}$. In spectra of $\mathrm{Fe}(\mathrm{CPC})_{2}$ and $\mathrm{Mn}(\mathrm{CPC})_{2}$ this vibration are shifted towards lower values of wave numbers 1579 and $1587 \mathrm{~cm}^{-1}$, respectively. Also, in the spectrum of pure $\mathrm{CPC}$, stretching $\mathrm{C}=\mathrm{O}$ bond is attributed to $1647 \mathrm{~cm}^{-1}$, which is in $\mathrm{Fe}(\mathrm{CPC})_{2}$ and $\mathrm{Mn}(\mathrm{CPC})_{2}$ spectra shifted towards lower values of wave numbers, 1639 and $1637 \mathrm{~cm}^{-1}$, respectively.

These shifts in IR spectra can be explained by the fact that the coordination atoms of nitrogen and oxygen engage lone electron pairs to form new bonds with metal center $\left(\mathrm{Fe}^{\mathrm{II}}, \mathrm{Mn}^{\mathrm{II}}\right)$, making these bonds slightly weak. This correlates with the fact that symmetric stretching vibration requires less energy, because the bond strength is in direct correlation with the bond energy.

The absorption spectra of CPC of moderate strength in the range of $1250 \mathrm{~cm}^{-1}$ ascribed to the symmetrical stretching of $\mathrm{C}-\mathrm{O}(\mathrm{H})$ bond, which are in spectra of $\mathrm{Fe}(\mathrm{CPC})_{2}$ and $\mathrm{Mn}(\mathrm{CPC})_{2}$ shifted towards higher values of wave numbers and are located in ranges 1242 and $1239 \mathrm{~cm}^{-1}$, respectively. This tendency can be explained by the fact that coordination $\mathrm{CPC}$ on $\mathrm{M}$ (II) produce deprotonation of oxygen from $\mathrm{OH}$ group on the five-membered ring and formation of $\mathrm{M}-\mathrm{O}$ bond, resulting in that the $\mathrm{C}-\mathrm{O}(\mathrm{H})$ bond is somewhat weaker than the $\mathrm{C}-\mathrm{O}(\mathrm{M})$ bond. If such weakening of $\mathrm{C}=\mathrm{N}$ and $\mathrm{C}=\mathrm{O}$ strength bonds and strengthen of $\mathrm{C}-\mathrm{O}$ bond take as crude measures, then new bands in low-wave areas around 461 and $486 \mathrm{~cm}^{-1}$ may be attributed to $\mathrm{Fe}-\mathrm{O}$ and $\mathrm{Mn}-\mathrm{O}$ bonds, respectively.

\section{UV spectra}

UV absorption spectra of an ethanol-water solution of $\mathrm{M}(\mathrm{II})$ ions, pure $\mathrm{CPC}$ and complexes $\mathrm{M}(\mathrm{CPC})_{2}$ interaction are shown in Fig.-10.

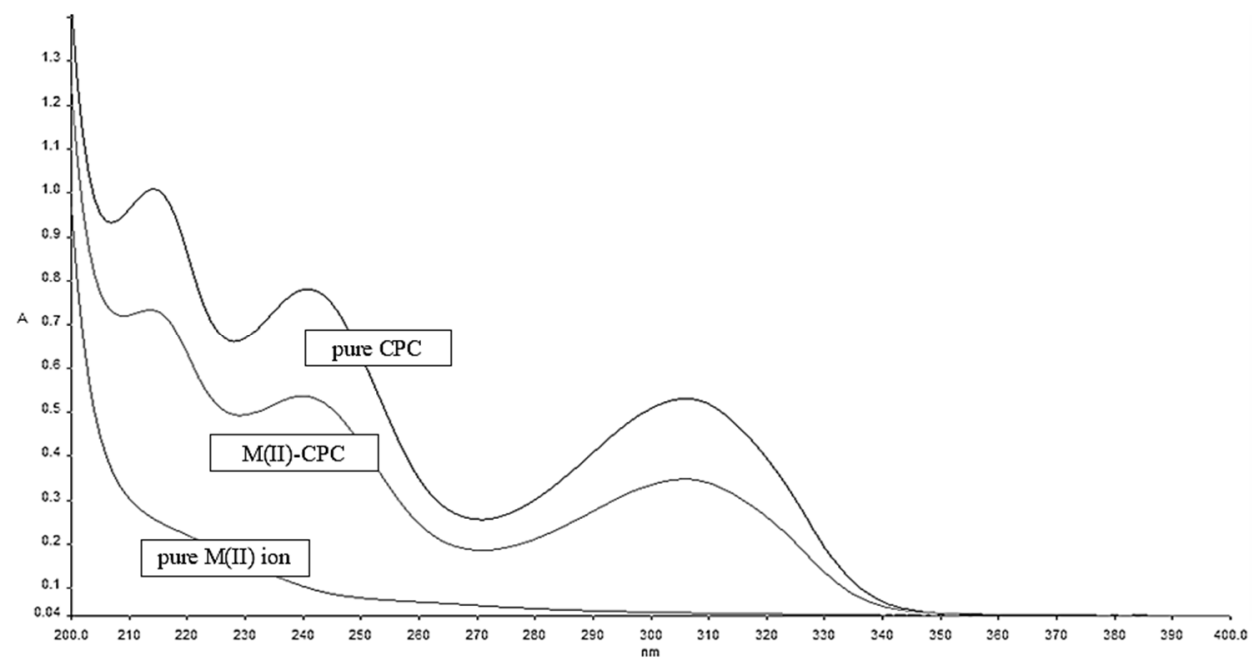

Fig.-10: UV spectra: $\mathrm{M}(\mathrm{II})$ ions, pure $\mathrm{CPC}$ and complexes $\mathrm{M}(\mathrm{CPC})_{2}$

UV spectra of pure CPC are relatively simple with three absorption maxima, at the 214, 240 and $305 \mathrm{~nm}$, which completely coincides with literature data. ${ }^{13}$ Binary model systems Fe(II)-CPC and Mn(II)-CPC show spectra with hypochromic shifted absorption maxima, at the same wave numbers. Those spectra are almost identical to the UV spectrum of Co(II)-CPC previously examined. ${ }^{28}$ Characteristic data of UV spectra from Fig. -10 are given in Table-3.

Based on the position of the highest absorption maximum for model systems, $\mathrm{Fe}(\mathrm{CPC})_{2}$ and $\mathrm{Mn}(\mathrm{CPC})_{2}$ at $214 \mathrm{~nm}$, the values of d-orbitals energy-splitting of both divalent cations are calculated. The obtained value is $559 \mathrm{~kJ} \mathrm{~mol}^{-1}$. For most metal complexes of the first series of d-elements, $\Delta$-values are usually lower than 
$400 \mathrm{~kJ} \mathrm{~mol}^{-1}$. Although both metals, iron and manganese, are elements of the first series, the value of energy splitting more than $400 \mathrm{~kJ} \mathrm{~mol}^{-1}$ indicates that CPC is a ligand with strong ligand field.

Table-3: UV spectral data of CPC and $\mathrm{M}(\mathrm{CPC})_{2}$ model-systems

\begin{tabular}{|c|c|c|}
\hline \multicolumn{3}{|c|}{ Capecitabin, $\mathrm{c}=0.32 \cdot 10^{-6} \mathrm{~mol} \mathrm{dm}{ }^{-3}(1=1 \mathrm{~cm}$, solvent: ethanol $/$ water, $80 / 20)$} \\
\hline Wavelength, $\lambda_{\max }[\mathrm{nm}]$ & Absorbance, A & Molar coeficient of absorption, $\varepsilon\left[\mathrm{cm}^{-1} \cdot \mathrm{mol}^{-1} \mathrm{dm}^{3}\right]$ \\
\hline 214 & 1.01 & $3.15 \cdot 10^{6}$ \\
\hline 240 & 0.78 & $2.43 \cdot 10^{6}$ \\
\hline 305 & 0.53 & $1.65 \cdot 10^{6}$ \\
\hline \multicolumn{3}{|c|}{$\begin{array}{l}\text { Capecitabin, } \mathrm{c}=0.32 \cdot 10^{-6} \mathrm{~mol} \mathrm{dm}{ }^{-3}, \mathrm{Fe}(\mathrm{II}) \text { and } \mathrm{Mn}(\mathrm{II}), \mathrm{c}=0.16 \cdot 10^{-6} \mathrm{~mol} \mathrm{dm}^{-3} \\
(\mathrm{l}=1 \mathrm{~cm} \text {, solvent: ethanol } / \text { water, } 80 / 20)\end{array}$} \\
\hline Wavelength, $\lambda_{\max }[\mathrm{nm}]$ & Absorbance, $\mathrm{A}$ & Molar coeficient of absorption, $\varepsilon\left[\mathrm{cm}^{-1} \cdot \mathrm{mol}^{-1} \mathrm{dm}^{3}\right]$ \\
\hline 214 & 0.75 & $3.12 \cdot 10^{6}$ \\
\hline 240 & 0.54 & $2.25 \cdot 10^{6}$ \\
\hline 305 & 0.34 & $1.41 \cdot 10^{6}$ \\
\hline
\end{tabular}

\section{Microscopic characterization of pure $\mathrm{CPC}$ and $\mathrm{M}(\mathrm{CPC})_{2}$}

Figure-11 shows microscopic images of pure CPC and products of $\mathrm{Fe}(\mathrm{II})$ and $\mathrm{Mn}$ (II) interaction with CPC.
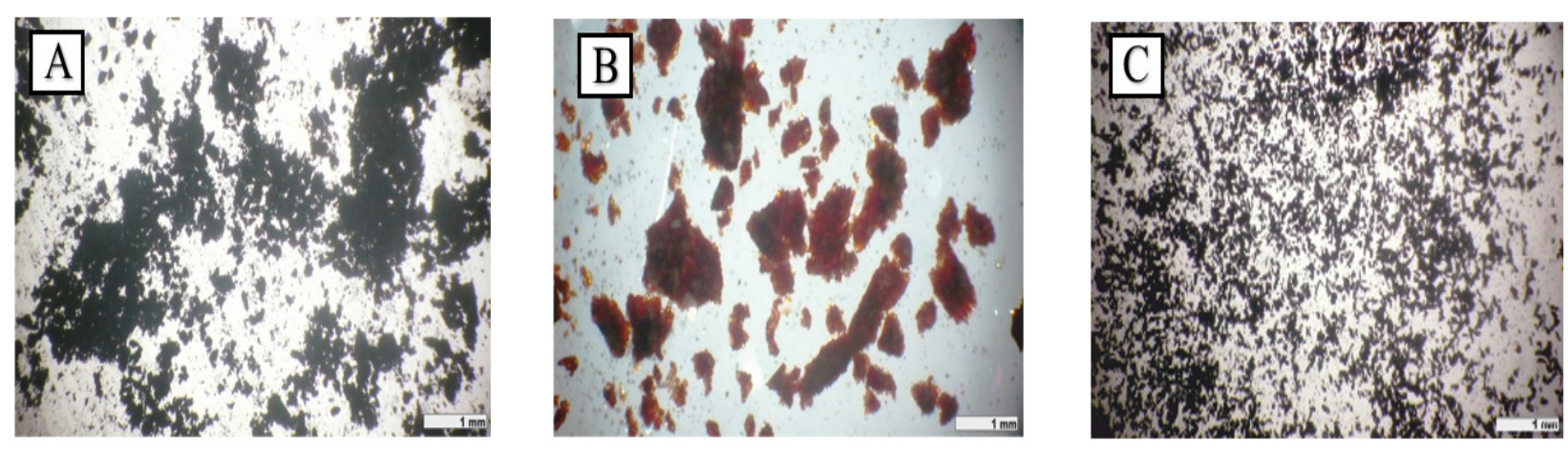

Fig.-11: Microscopic images of: (A) pure CPC, (B) Fe(CPC $)_{2},(\mathrm{C}) \mathrm{Mn}(\mathrm{CPC})_{2}$

Microscopic image of pure capecitabine shows that it is an organic compound with the fine-grained crystal structure. Comparing microscopic images of pure $\mathrm{CPC}$ and $\mathrm{Fe}(\mathrm{CPC})_{2}$ complex, significant differences in sizes and images of crystals are visible. $\mathrm{Fe}(\mathrm{CPC})_{2}$ product has reddish brown large crystals indicating the presence of $\mathrm{Fe}(\mathrm{II})$ ions. $\mathrm{Mn}(\mathrm{CPC})_{2}$ product has a fine-grained crystal structure similar to the pure ligand.

\section{CONCLUSION}

Based on the results obtained by spectroscopic methods (FT-IR and UV), and comparing the microscopic images of pure ligand and the resulting products, we can conclude that the interaction between capecitabine and metal ions, Fe(II) and $\mathrm{Mn}$ (II), occurred. As the most relevant confirmation for interaction, FT-IR analysis of obtained complexes exactly indicates on interactions between these ions with $\mathrm{O}$ and $\mathrm{N}$ donor atoms of CPC as an organic ligand. Considering that CPC is usually used in treatments of malignant diseases, it can be assumed that one of the reasons why capecitabine has to be applied in higher doses is it's decreased effectivity due to the formation of complexes with biometals.

\section{REFERENCES}

1. N. S. Krstić, R. S. Nikolić, M. N. Stanković, N. G. Nikolić, D. M. Đorđević, Tropical Journal of Pharmaceutical Research, 14(2), 337(2015).

2. C. Dendrinou-Samara, G. Tsotsou, L. V. Ekateriniadou, A. H. Kortsaris, C. P. Raptopoulou, A. Terzis, D. A. Kyriakidis, D. P. Kessissoglou, Journal of Inorganic Biochemistry, 71, 171(1998). 
3. A. Andrade, S. F. Namora, R. G. Woisky, G. Wiezel, R. Najjar, J. A. A. Sertie, D. de Oliveira Silva, Journal of Inorganic Biochemistry, 81(1-2), 23(2000).

4. N. H. Gokhale, S. S. Padhye, S. B. Padhye, C. E. Anson, A. K. Powell, Inorganica Chimica Acta, 319(12), 90(2001).

5. Z. Travniček, M. Malon, Z. Šindelar, K. Doležal, J. Rolčik, V, Kryštof, M. Strnad, J, Marek, Journal of Inorganic Biochemistry, 84 (1-2), 23(2001).

6. S. Tabchi and J. Kattan, Journal of Cancer Research \& Therapy 2(5), 82(2014).

7. R. Kandimalla and D. Nagavally, International Research Journal of Pharmacy, 3(11), 163(2012).

8. M. Summerhayes, Journal of Oncology Pharmacy Practice, 8(1), 1(2002).

9. N. Devanaboyina, S. Y. Kishore, P. Pushpalatha, N. Mamatha, P. Venkatesh, International Journal of Science Inventions Today, 2(1), 21(2013).

10. F. Anjum, T. Radhika, K. R. Kumari, M. Ajitha, International Research Journal of Pharmacy, 3(3), 177(2012).

11. S. Frings, Onkologie, 21, 451(1998).

12. T. Sreenivasa Rao, K. Sukanya, S. Chandanam, G. H. Akkamma, S. Sai Kumar and Manogna, Research Journal of Pharmaceutical, Biological and Chemical Sciences, 3(3), 713(2012).

13. E. Piorkowska, M. Kaza, J. Fitatiuk, I. Szlaska, T. Pawinski, P. J. Rudzki, Pharmazie, 69, 500 (2014).

14. P. Kathiravan and V. P. Pandey, International Journal of PharmTech Research, 6(5), 1633(2014).

15. F. Desmoulin, V. Gilard, M. Malet-Martino, R. Martino, Drug Metabolism and Disposition, 30(11), 1221(2002).

16. M. Malet Martino and R. Martino, The Oncologist, 7(4), 288(2002).

17. J. L. Beard, The Journal of Nutrition, 131(2), 568S(2001).

18. N. Abbaspour, R. Hurrell, R. Kelishadi, J. Res. Med. Sci., 19(2), 164(2014).

19. J. Wang and K. Pantopoulos, Biochemical Journal. 434(3), 365(2011).

20. C. P. Gupta, IOSR Journal of Applied Chemistry, 7(11), 38(2014).

21. M. Đokić and N. Bilandžić, Meso, 14(3), 232(2012).

22. A. P. Golombek and M. P. Hendrich, Journal of Magnetic Resonance, 165, 33(2003).

23. D. E. Ash, The Journal of Nutrition, 134(10), 2760S(2004).

24. S. Grgurić-Šipka, Hemija bioelemenata, Hemijski fakultet Univerziteta u Beogradu, Beograd, p. 107, 108 (2014).

25. F. Z. Kanyo, R. L. Scolnick, L, E. D. Ash, W. D. Christianson, Nature, 383, 554(1996).

26. S. Sunkara, D. Sravanthi, K. M. Maheswari, S. Salma, B.N. Nalluri, Journal of Chemical and Pharmaceutical Research, 5(1), 320(2013).

27. D. Jothieswari, B. Chandraobulreddy, G. SwarnaLatha, I. Sowkar Baig, K. Bhaskar Reddyand, K Dhanalakshmi, International Journal of Medicinal Chemistry \& Analysis, 4(5), 279(2014).

28. A. Cipurković, E. Horozić, A. Crnkić, S. Marić, N. Ljubijankić, Bulletin of the Chemists and Technologists of Bosnia and Herzegovina, 47, 11(2016).

[RJC-1905/2017] 